Dehumanization, moral disengagement, and public attitudes to crime and punishment

Milica Vasiljevic and G. Tendayi Viki

University of Kent

In P.G. Bain, J. Vaes, \& J-Ph. Leyens (Eds). Humanness and dehumanization.

Hove: Psychology Press. 
"He's an animal. A terrible animal," said Carl Elliott... whose daughter was Gore's... final victim.

"He's worse than an animal. He was an evil monster," Jeanne Elliott, Lynn's mother...

Extracts taken from: David Alan Gore Execution: Lethal Injection For Florida Rapist And Murderer Described As 'Devil' (http://www.huffingtonpost.com/2012/04/12/david-alan-gore-execution-lynn-elliottkiller_n_1418113.html)

The above extracts illustrate the tendency for some members of society to view criminals as animals or subhuman savages. Contemporary media images often conjure monstrous images of criminal savages that do not deserve public compassion. This perception of criminal offenders is not just a contemporary phenomenon; it has historical precedent. As early as 1876, Cesare Lombroso argued that certain people are born criminal or delinquente nato (Lombroso, 1876). Lombroso argued that criminals had physical and psychological anomalies that were similar to those of primitive peoples and animals. He referred to criminals as atavistic savages and set out on a pseudo-scientific quest to document their subhuman characteristics. Lombroso's approach represents the dehumanization of offenders which was characteristic of the second half of the $19^{\text {th }}$ century (Jahoda, 1999). According to Jahoda (1999), such dehumanization also extended to the poor, the mentally ill and women. Interestingly, some of these views still influence people's judgements of criminals in contemporary western society (e.g.: Goff, Eberhardt, Williams, \& Jackson, 2008).

The importance of public attitudes towards criminals and the criminal justice system (CJS) cannot be denied. In modern democracies that are not based on coercive policing, the legitimacy of the CJS depends on the willing participation of members of the public (Viki \& Bohner, 2008). The public's willingness to participate and support the CJS depends strongly on their attitudes towards the criminal justice process (Viki, Culmer, Eller, \& Abrams, 2006; 
Wood \& Viki, 2004). Indeed, Kaukinen and Colavechia (1999) note that when the public hold negative attitudes towards the CJS, they are much more likely to engage in vigilante forms of justice. Such public attitudes also have a significant impact on political and media discourse (Wood \& Viki, 2004). If criminality is viewed in essentialistic ways and criminals are regarded as non-reforming savages, then public attitudes are likely to be negative and result in highly punitive approaches to criminal justice (Kury \& Ferdinand, 1999).

The USA provides an example of a legal system that has increasingly become more punitive over the last thirty years. Recent figures from the International Centre for Prison Studies show that the USA has the highest prison rate population in the world with 743 per 100,000 of the national population, followed by Rwanda with 595, and Russia with 568 (Walmsley, 2011). Some scholars pin this rise in the prison population to the changing focus from rehabilitation to punishment which has happened since the 1970's (Loury, 2008). Other scholars like Yeomans (2010) explain this recent focus on punitiveness as resulting from the interconnections between the media, public opinion, political trends, and legislative changes. According to Yeomans (2010), the media portrayals of crime are inextricably linked to public opinion which in turn influences the stances taken by politicians that in the end are transformed into legislative changes (cf. Wood \& Viki, 2004).

In such social contexts, the rehabilitation of offenders can become a contentious issue. Since some offenders will eventually be released into the community, their successful rehabilitation should become the priority. However, despite the importance of offender rehabilitation, the public is often sceptical about the benefits of psychological interventions and rehabilitation programmes (Sample \& Bray, 2006; Sundt, Cullen, Applegate, \& Turner, 1998), and also often believes that offenders have relatively high recidivism rates (Levenson, Brannon, Fortney, \& Baker, 2007). In fact, research evidence shows that rehabilitation 
programmes are effective in reducing reoffending (Cullen, 2002; Cullen \& Gendreau, 2000); whilst "get tough" correctional programmes do not appear to have much impact on recidivism (Cullen, Pratt, Miceli, \&Moon, 2002). Furthermore, research actually suggests that community based rehabilitation programmes are more successful than those completed in prison (Howells \& Day, 1999). Such rehabilitation programmes cannot succeed without the support of the public. As such, public attitudes towards crime, punishment and rehabilitation can have a bearing upon the outcomes of offenders. We propose that one important aspect of understanding public attitudes to crime and punishment is dehumanization of offenders.

In this chapter, we present a model of the dehumanization of offenders which leads to their expulsion from the moral arena, and subsequent negation of their prospects of rehabilitation. We connect the literature on dehumanization, moral exclusion, and public attitudes to crime and punishment. In so doing, we develop a model of offender dehumanization which argues that once dehumanized offenders are expelled from the moral community, their negative treatment is seen as justified. We begin the chapter by reviewing dehumanization theory and research to date, and then overview the literature connecting dehumanization and moral exclusion. This serves as a basis for our theoretical treatise on how the phenomenon of dehumanization can be related to public attitudes towards offenders. In this part, we present empirical research that has been conduced thus far on the topic of offender dehumanization. Although, research on offender dehumanization is still in its infancy, studies that have been conducted so far suggest that there is a relationship between dehumanization and greater punitiveness. We go on to propose a link between the literature on intergroup dehumanization and public attitudes towards offenders by highlighting the greater incarceration rates of racial minorities. Then we present recent research distinguishing between animalistic and mechanistic dehumanization, and attempt to relate it to offender punishment. Finally, we turn our attention to how offender dehumanization can be 
ameliorated. We end this chapter by concluding how research on dehumanization can have an impact on offender punishment and rehabilitation.

\section{Dehumanization Theory and Research}

As noted above, dehumanizing language is often used to describe offenders. However, there is very little contemporary research that has examined the role of dehumanization in public attitudes towards offenders. As is clear from most of the chapters in this book, research has focused on the role of dehumanization in social and intergroup contexts (e.g. Demoulin et al., 2004; Leyens et al., 2001, Viki et al., 2006). Based on the earlier work of Leyens and colleagues on infrahumanization (e.g. Demoulin et al., 2004; Leyens et al., 2000), Haslam (2006) developed a theoretical approach that differentiates two types of dehumanization. Animalistic dehumanization refers to the denial of attributes that are uniquely human (e.g. civility and moral sensibility). Such a denial results in certain people or social groups being perceived as animal-like. In contrast, mechanistic dehumanization refers to the denial of human nature traits such as interpersonal warmth. This denial results in certain people or social groups being perceived as machine-like.

Within the context of intergroup relations, several researchers have shown that people have a tendency to view their ingroup as being more human than other groups. For example, research by Leyens and colleagues has shown that people attribute more secondary or uniquely human emotions to their ingroup than they do to relevant outgroups (e.g. Demoulin et al., 2004; Leyens et al., 2001; Paladino, Leyens, Rodriguez, \& Rodriguez, 2002). Similar findings have been reported by Viki et al. (2006) who asked participants to attribute human words (e.g., person and humanity) and animal words (e.g., creature and animal) to their ingroup versus an outgroup. The results indicated that human-related words were attributed to the ingroup more than the outgroup (Viki et al., 2006). Other research has shown that people 
tend to view themselves as possessing more human nature traits than others (e.g. Haslam \& Bain, 2007). Over the last decade, researchers have demonstrated that dehumanization can be a relatively common phenomenon that can range from the subtle to more serious and explicitly negative characterizations of certain groups of people (Haslam \& Loughnan, 2012).

\section{Dehumanization and Moral Exclusion}

An interesting question to examine concerns the potential consequences of dehumanization with regards to the perceptions and treatment of others. Perceiving particular groups or individuals as subhuman can form the basis for justifying social and moral exclusion (Bar-Tal, 1990; Opotow, 1990; Staub, 1989). Early social psychological writings on dehumanization and mass violence identified two aspects of humanity: "identity" and “community" (Kelman, 1973). According to Kelman, an individual who is given identity is distinguished in his own right from others, and is given the right to make choices and live by their values. Furthermore, such an individual is considered part of a larger community of individuals who respect each other's rights. This humanized individual is not viewed as a potential target for negative treatment. In contrast, the negative treatment of an individual who is perceived as lacking in identity and community is highly likely. Kelman and other scholars such as Bar-Tal (1990), Opotow (1990), and Staub (1989), connected this dehumanization of victims to mass atrocities, such as genocide and ethnic cleansing.

According to Bandura (1990a; 1990b), dehumanization is one of the factors related to moral disengagement, allowing people to justify negative behavior against particular targets. Such moral exclusion can facilitate aggression because dehumanized targets are viewed as being outside the moral boundaries of society (Opotow, 1990). Consistent with this argument, Baumeister, Stillwell and Heatherton (1994) propose that the dehumanization of victims may inhibit feelings of guilt and distress about any harm inflicted. Recent empirical studies have 
demonstrated the negative consequences of dehumanization. For example, Cuddy, Rock, and Norton (2007) found that people were less willing to help victims of Hurricane Katrina, to the extent that they perceived them as less human. Similarly, Zebel, Zimmermann, Viki and Doosje (2008) found that people were less likely to feel guilty about wrongs perpetrated by their ingroup against an outgroup, if they perceived the outgroup as less human than their ingroup. Taking these findings further, Leidner, Castano, Zaiser, and Giner-Sorolla (2010), found that moral disengagement strategies of which dehumanization is part, are used as psychological mechanisms that allow individuals to distance themselves from past ingroup violence, and lead to a decreased willingness to punish ingroup perpetrators and offer compensation to ingroup victims. Overall, research so far strongly demonstrates that dehumanization inhibits the experience of moral emotions and increases the likelihood of negative behavior towards certain groups and individuals (see also Castano \& Giner-Sorolla, 2006; Tam et al., 2007, Vaes, Paladino, Castelli, Leyens, \& Giovanazzi, 2003).

\section{Dehumanization and Offenders}

In this chapter, we explore the potential dehumanization of offenders and some potential consequences. It can be argued that by virtue of their behaviour, offenders have removed themselves from the moral boundaries of society. Indeed, Kelman (1973) argues that as an individual “...gradually discards personal responsibility and human empathy, he loses his capacity to act as a moral being” (p. 52). By performing criminal acts society may view offenders as having denied themselves the right to make choices on their own, and also as having forfeited their right to be members of the community. By committing acts that are not condoned by the community, they are dehumanized and excluded from the human moral circle (cf. Singer, 1981). Once expelled from the human moral circle, and assigned as savage subhumans, offenders can then be harshly punished and ill-treated for what they have done. 
There is currently very little research that has directly examined the dehumanization of offenders and its consequences. Below, we will review some of the research that has begun to explore this issue. The majority of this research has focused on the animalistic dehumanization of offenders. This focus makes sense if one considers that people are classified as criminals, to the extent that their behavior violates social and legal norms. Such norms are often assumed to be the cornerstone of civilized society. As such, individuals who violate these norms could be perceived as lacking in civility and moral sensibility. Haslam (2006) defines animalistic dehumanization as the denial of uniquely human characteristics such as civility and moral sensibility. It is, therefore, not surprising that criminals would be dehumanized using animalistic terms; their behavior violates what is perceived an important part of being human. Such dehumanization is likely to result in public support for the punitive treatment of offenders.

In an interesting study, Myers, Godwin, Latter, and Winstanley (2004) tested whether dehumanizing language in victim impact statements influences mock-jurors decisions regarding the death penalty. Victim impact statements are given during the sentencing phase of trials, mainly serving to portray the victim and the impact of the crime on the victim and their family. Myers and colleagues note that more often than not these victim impact statements contain humanizing language to describe the victim, whereby the jury learns of the personal characteristics and values of the victim. However, these statements are not just used to remind juries of the humanness of the victim, but also to highlight to jurors that the defendant is subhuman, and therefore not worthy of compassion. Myers and colleagues (2004) demonstrated that there is a tendency for jury-eligible respondents to make more punitive judgements when the victim impact statement contained dehumanizing language about the defendant. Although, results did not reach statistical significance a larger number of participants who read a dehumanizing victim impact statement opted for the death penalty, 
when compared to respondents who read a neutral or humanizing statement. These results warrant further investigation in how dehumanizing language may influence sentencing and rehabilitation decisions taken by juries.

In a related vein, Osofsky, Bandura, and Zimbardo (2005) showed that various forms of moral disengagement including dehumanization enable prison staff to carry out the death penalty. Importantly, this study was tested on three different groups of prison staff: the execution teams who carry out the death penalty; the support teams who provide emotional support and solace to the condemned inmate and the families of the victims; and prison guards who are not part of the execution process. Interestingly, the execution teams demonstrated the highest level of dehumanization and denial of personal responsibility regarding the executions, whereas the support teams demonstrated the lowest level of offender dehumanization.

In a recent theoretical piece, Giner-Sorolla, Leidner and Castano (2011) advanced the idea that criminals are not just dehumanized but are also demonized as malignant and incapable of reform. This demonization, which can be conceived as a more radical form of dehumanization, gives people a moral mandate to take extreme measures, including violence against offenders (cf. Skitka, 2002; Skitka \& Mullen, 2002). Thus, the above findings showing that dehumanization leads to support for the death penalty and willingness to execute the offender can be related to this notion of demonization. Thought of as demons that are beyond any redemption both jurors and prison staff may believe that rehabilitation is not possible, and therefore support the death sentencing and annihilation of offenders.

An illustration of this notion of demonization is given by Waldram (2009). In this ethnographic study Waldram asked sex offenders about their offenses and possibility of rehabilitation. The study showed that although public discourse labels offenders as "evil" in 
essentialist terms, and thereby beyond rehabilitation; the view of the offenders themselves is that they have done bad acts, but they reject the label of "evil" in essentialist terms, and also believe they can be rehabilitated. Obviously, this type of discourse can have very profound impact on whether rehabilitation or punishment is supported for offenders. Waldram (2009) reminds us that many offenders will be released into our communities, because after all they are human despite the public trying to strip them of their humanness.

In a series of studies conducted by our lab, we tested the conjectured relationship between dehumanization and moral exclusion as predictors of penal attitudes towards sex offenders (Viki, Fullerton, Raggett, Tait, \& Wiltshire, in press). Although, the media is filled with gruesome dehumanizing reports of sex offenders on a daily basis (Gavin, 2005; Soothill \& Walby, 1991), we wished to explore whether the public subscribes to this view. In the first study we asked members of the public to rate the extent to which different words could be used to describe either paedophiles or rapists. The words used were taken from Viki et al. (2006), and they symbolised either human or animal attributes (i.e. humanity, person, people vs. creature, beast, animal). We then asked participants to express their attitudes towards the rehabilitation of sex offenders, and their recommended sentence for sex offenders who are found guilty. The results of this study showed that the more participants' dehumanized sex offenders, the less they supported offender rehabilitation. Furthermore, the more they dehumanized offenders, the higher the sentences they recommended. There was also a trend for participants to recommend higher sentences for the paedophile when compared to the rapist as a function of their levels of dehumanization (Viki et al., in press).

In a second study, we asked members of the general public to rate the two types of sex offenders on the same scale of dehumanization. Unlike our first study, we replaced the term paedophile with the more descriptive term; child molester. Moreover, in this study we were 
interested in testing whether dehumanization of offenders would lead to their social exclusion from the community. We, therefore, asked participants to indicate their agreement with statements such as; "rapists should be excluded from society". This measure was adapted from Opotow, Gerson and Woodside (2005). Our results supported our hypotheses, showing that participants were more in favour of the social exclusion of offenders, the more they dehumanized them. Furthermore, this study again showed that judgments of social exclusion were more severe when participants thought about the child molester than the rapist (Viki et al., in press). The findings of this study are important in that they advance our knowledge of how dehumanization can lead to social exclusion of offenders.

Considering our finding that people are more punitive towards sex offenders who commit offences against children, we decided in our next study to concentrate only on child sex offenders. As an extension to the previous studies, we manipulated the age of the child victim (6 vs. 15 years). We also asked participants to indicate the extent to which they would support violence against sex offenders, such as castration or murder. In line with our previous results, we found that the more participants dehumanized the offenders, the more participants supported their social exclusion from the community, and also their violent ill treatment. Importantly, participants' level of punitiveness did not differ as a function of the age of the victim (Viki, et al., in press). These results highlight that to the extent that members of the general public see offenders as less than human, they are willing to exclude offenders from their community and support violence against offenders such as castration and murder.

Our research demonstrates the role of dehumanization in public attitudes toward a particular type of offender (i.e. sex offenders). We propose that a similar pattern of results should emerge if researchers test these hypotheses with other kinds of offenders. One caveat would be that the relationship between dehumanization and public attitudes may not be so 
negative toward these other types of criminals given the pernicious quality of crime that sexual offenders characterise (Levenson, Brannon, Fortney, \& Baker, 2007).

\section{Are Criminals in the Outgroup?}

As noted earlier, dehumanization researchers have mostly focused on its role in intergroup relations (e.g. Leyens et al., 2001; Demoulin et al, 2009; Viki et al. 2006). In this context, the dehumanization of offenders may not be considered as a strictly intergroup phenomenon. However, it is important to note that certain social groups may be associated with criminality more than others. As Ferrell, Hayward, and Young (2008) point out, the penal system is the result of a dehumanizing political rhetoric, but also the symbiotic relationship between prison and the ghetto. Thus, some of the findings from the dehumanization literature could be applied to our understanding of attitudes towards offenders. In particular, the "essentialistic" features of dehumanization can be used to explain the higher incarceration rates of ethnic and racial minorities (cf. Clear, 2007; Mann, 1989; Roberts, 2004; Yeomans, 2010).

In a comprehensive programme of study Jennifer Eberhardt and colleagues have examined the relationship between race and perceptions of criminality. Their studies showed that activating abstract concepts of crime induces both members of the public and police officers to shift their attention towards Black male faces. Conversely, presenting people with Black faces below the threshold of their conscious awareness also made them quicker to recognise crime related objects such as guns. Importantly, they showed that when faces were judged as more stereotypical of the Black race, they were also rated as more criminal (Eberhardt, Goff, Purdie, \& Davies, 2004). The effects of race stereotypicality were found to have far reaching consequences when pictures of actual Black defendants were examined. Results showed that Black defendants, who looked more stereotypically Black and were tried 
for murdering a White victim, were more likely to be sentenced to death when compared to Black defendants who looked less typically Black, and who murdered a Black victim (Eberhardt, Davies, Purdie-Vaughns, \& Johnson, 2006). In a similar vein, Blair, Judd, and Chapleau (2004), examined actual incarcerations in the state of Florida, and demonstrated that both Black and White defendants who had equivalent criminal histories and came from the same racial group received a longer jail sentence the more Afrocentric their features were. These effects could bring offender sentencing into the intergroup domain (Prentice \& Miller, 1999), and could relate them more generally to dehumanization.

Of particular interest to this chapter are the findings by Goff, Eberhardt, Williams, and Jackson (2008) showing that people implicitly associate Blacks with apes, even without any explicit knowledge of historic renditions of "racial science". Crucially, this dehumanizing association has grave consequences for the judgments of Black offenders. Participants were more likely to condone and justify a beating by police officers if the suspect was described as Black. Moreover, analysing archival reports of actual death-eligible cases in Philadelphia between 1979 and 1999, Goff and colleagues (2008) found that death sentencing of Black defendants could be predicted by the more apelike metaphorical language utilised by newspapers to describe the specific offenders.

In a recent series of studies, we examined the role of dehumanization in people's views concerning Muslim prisoners. The first study was conducted two weeks after the prisoner suicide at Guantanamo Bay in 2006 (Viki, Zimmerman, Ballantyne, Winchester \& Measor, 2011). Participants, who indicated their religion as Christian, were asked to attribute humanity and animality to both Muslims and Christians using the Viki et al. (2006) measure. After this, participants were reminded of the prisoner suicides at Guantanamo Bay. They were then asked to indicate their level of agreement with statements that blamed the victims 
(e.g. "These prisoners killed themselves for attention"). We found that participants attributed more humanity to their ingroup (i.e. Christians) versus the outgroup (i.e. Muslims). More importantly, we found that to the extent that participants dehumanized Muslims, they were more likely to blame the prisoners for their suicides.

In another study, we examined people's self-reported likelihood that they would torture Muslim prisoners (Viki, 2011).This study was conducted after reports of torture from the Abu Ghraib prison in Iraq emerged. Participants were asked to attribute humanity to Muslims and Christians (cf. Viki et al., 2006). After this, participants were then presented with four images of torture from the Abu Ghraib prison. They were asked to imagine themselves in the same situation and then indicate the likelihood that they would do the same things that the soldiers were doing to the prisoners. We again found that participants attributed more humanity to their ingroup versus outgroup. Furthermore, to the extent that Christian participants dehumanized Muslims, they reported a higher likelihood that they would also torture Muslims like the soldiers in the images.

All these findings are consistent with the research concerning the dehumanization of offenders we reported earlier (e.g. Viki et al., in press). Consistent with Viki et al. (in press), the above research also shows that to the extent that offenders are dehumanized, people are likely to support their punitive treatment. The above research is also interesting because it adds an intergroup dimension to the findings. The research shows that when offenders belong to dehumanized outgroups, they are also likely to suffer punitive treatment.

\section{Animalistic Offenders versus Mechanistic Offenders}

As noted above, Haslam (2006) distinguishes animalistic dehumanization and mechanistic dehumanization. This distinction gave rise to a fruitful series of projects that 
examined the effects of the two different types of dehumanization (Haslam, Bain, Douge, Lee, \& Bastian, 2005; Haslam, Kashima, Loughnan, Shi, \& Suitner, 2008; Loughnan \& Haslam, 2007). For our purposes, we have noted that this distinction is useful in identifying that most discourse on offenders largely uses animalistic dehumanization. However, we also note that in some circumstances, such as white-collar crime, offenders may be likened to machines. Future researchers should investigate the differential effects arising from animalistic and mechanistic dehumanization of offenders.

A potential approach to examine the role of mechanistic dehumanization could be based on recent research by Bastian, Laham, Wilson, Haslam, and Koval, 2011. This research examined moral typecasting which is the notion that people can be viewed as either moral agents or moral patients (Bastian et al., 2011). This distinction can form the basis for assigning intention and blame, or experience and pain respectively (Gray \& Wegner, 2009). According to Bastian et al. (2011) human uniqueness is related with attributions of inhibitive moral agency, whereas human nature is related with proactive agency and moral patiency. Across two studies, they found that people and groups that were seen to be high in human uniqueness were held morally responsible or blameworthy for immoral (bad) behaviour, and thereby they are seen as deserving of punishment. On the other hand, individuals and groups high in human nature, were more morally praised for moral acts (proactive agency), and are seen as deserving of protection from immoral behaviour (patiency).

Bastian et al. (2011) also found that attributions of high human nature led to greater endorsement of rehabilitation for these groups and individuals. These results could be connected to the realm of offender dehumanization and punishment. It could be hypothesised that offenders are thought of as moral agents who are automatically assigned the ability to inhibit their impulses. However, once they offend, they lose their moral status, and the public 
is in favour of harsh punishment, precisely because as moral agents they did not exercise their ability to inhibit their impulses. This idea is in line with western legal traditions that highlight individual responsibility through the concepts of actus rea and mens rea (Hamdani, 2007). Future research could explore these issues more directly.

\section{Ameliorating offender dehumanization}

The studies discussed in this chapter demonstrate the potent effects of dehumanization on attitudes towards offenders. Given the ever rising numbers of incarceration rates, and the public support for violent treatment of offenders, it is imperative for social scientists to find ways in which to tackle the negative consequences of offender dehumanization. Prior research has demonstrated that high quality relationships between correctional staff and offenders can lead to more effective rehabilitation (Andrews \& Keissling, 1990; Ward \& Brown, 2004). Moreover, recidivism rates were found to correlate with the quality of interpersonal relationships between correctional staff and offenders (Dowden \& Andrews, 2004). Therefore, we propose that one way to decrease dehumanization of offenders is by engaging in high quality contact with them (Allport, 1954). This notion is consistent with previous research that has shown that contact between groups is a powerful way to reduce prejudice (Tropp \& Pettigrew, 2009).

With this in mind, we examined the possibility of ameliorating dehumanization towards sex offenders, and thereby improving public support for their rehabilitation via intergroup contact (Viki et al., in press). We conducted a study in which we tested the tenets of the contact hypothesis using a sample of members of the general public and a sample of people who work in a community based rehabilitation centre for sex offenders. Measures of participants' contact quality and quantity with sex offenders were taken, as well as measures of dehumanization and attitudes towards rehabilitation. As expected, correctional staff 
dehumanized sex offenders less, and supported their rehabilitation more than the members of the general public. Mediational analyses confirmed that higher support for rehabilitation was due to the lowered dehumanization amongst the two samples. Furthermore, it was found that in the sample of correctional staff higher quality of contact led to lower dehumanization which in turn lowered their punitiveness towards the sex offenders.

One obvious drawback to the contact hypothesis is that members of the general public may avoid contact with offenders. As such, other ways of ameliorating dehumanization and encouraging contact may be required. Imagined contact, an extension to the classical contact paradigm, shows the beneficial aspects of contact with the added benefit that it avoids the anxiety provoking emotions that accompany real instances of contact with the outgroup (Crisp \& Turner, 2009). Training people to imagine contact with offenders may be a viable way of reducing the dehumanization of offenders. Another potential approach would be to increase people's empathy and perspective taking towards offenders (Lord, Lepper, \& Preston, 1984; Unnever, Cullen, \& Fisher, 2005; Unnever \& Cullen, 2009). For example, a study by Johnson et al. (2002) demonstrated that when participants are induced to feel empathy, they assign more situational attributions and recommend less severe punishment to a hypothetical defendant who was tried for grand larceny. More research is also needed to further examine these issues.

\section{Conclusion}

This chapter attempted to review and reconcile the literature on public attitudes towards offender punishment and rehabilitation as a function of dehumanization. We discussed how dehumanization of offenders leads to their expulsion from the moral community, which we postulated to be imperative in the opinions of the public as regards to punishment and rehabilitation. Recent research provided us with evidence that 
dehumanization of offenders leads to attitudes that offenders cannot be rehabilitated, and are deserving of harsher punishment, including more extreme assignments of torture and the death penalty. We also connected the literature on intergroup dehumanization with public views of crime and offenders. This dehumanization was taken as a useful framework to explain the higher rates of incarceration among racial and ethnic minorities. We also extended our analysis to the realm of animalistic and mechanistic dehumanization, and suggested some plausible avenues for further research. We also presented some of our own research which has directly investigated the link between dehumanization and public views on rehabilitation and punishment of offenders. Finally, we discussed avenues for the humanization of offenders and their subsequent reacceptance into the moral community from which they were expelled. Although this area is in its nascent stages, we strongly believe that it provides a powerful avenue for exploring dehumanization and its consequences. 


\section{References:}

Allport, G.W. (1954). The nature of prejudice. Reading, MA: Addison-Wesley.

Andrews, D. A., \& Keissling, J. J. (1980). Programme structure and effective correctional practice: A summary of the CaVic research. In R.R. Ross and P. Gendreau (Eds). Effective Correctional Treatment. Toronto, Canada: Butterworth.

Bandura, A. (1990a). Selective Activation and Disengagement of Moral Control. Journal of Social Issues, 46, 27-46. doi: 10.1111/j.1540-4560.1990.tb00270.x

Bandura, A. (1990b). Mechanisms of moral disengagement. In W. Reich (Ed.), Origins of terrorism: Psychologies, ideologies, theologies, states of mind (pp. 161-191). Cambridge: Cambridge University Press.

Bar-Tal, D. (1990). Causes and consequences of delegitimization: Models of conflict and ethnocentrism. Journal of Social Issues, 46, 65-81. doi: 10.1111/j.15404560.1990.tb00272.x

Bastian, B., Laham, S. M., Wilson, S., Haslam, N., \& Koval, P. (2011). Blaming, praising, and protecting our humanity: The implications of everyday dehumanization for judgments of moral status. British Journal of Social Psychology, 50, 469-483. doi: 10.1348/014466610X521383

Baumeister, R. F., Stillwell, A. M., \& Heatherton, T. F. (1994). Guilt: An interpersonal approach. Psychological Bulletin, 115, 243-267. doi: 10.1037/0033-2909.115.2.243 
Blair, I., Judd, C. M., \& Chapleau, K. M. (2004). The Influence of Afrocentric Facial Features in Criminal Sentencing. Psychological Science, 15, 674-679. doi: 10.1111/j.0956-7976.2004.00739.x

Castano, E., \& Giner-Sorolla, R. (2006). Not quite human: Infrahumanization in response to collective responsibility for intergroup killing. Journal of Personality and Social Psychology, 90, 804-818. doi: 10.1037/0022-3514.90.5.804

Clear, T. R. (2007). Imprisoning Communities: How Mass Incarceration Makes Disadvantaged Neighborhoods Worse. New York: Oxford University Press.

Crisp, R. J., \& Turner, R. N. (2009). Can imagined interactions produce positive perceptions? Reducing prejudice through simulated social contact. American Psychologist, 64, 231240. doi: $10.1037 / \mathrm{a} 0014718$

Cuddy, A.J.C., Rock, M.S., \& Norton, M.I. (2007). Aid in the aftermath of Hurricane Katrina: Inferences of secondary emotions and intergroup helping. Group Processes and Intergroup Relations, 10, 107-118. doi: 10.1177/1368430207071344

Cullen, F. T. (2002). Rehabilitation and treatment programs. In Crime: Public Policies for Crime Control, eds. J. Q. Wilson and J. Petersilia, pp. 253-90. Oakland, CA: ICS Press.

Cullen, F. T., \& Gendreau, P. (2000). Assessing correctional rehabilitation: policy, practice and prospects. In Policies, Processes, and Decisions of the Criminal Justice System, Criminal Justice 2000, vol. 3, ed. J. Horney, pp. 109-76. Washington, DC: National Institute of Justice.

Cullen, F. T., Pratt, T. C., Miceli, S. L., \& Moon, M. M. (2002). Dangerous liaison? Rational choice theory as the basis for correctional intervention. In Rational choice and criminal behavior: Recent research and future challenges, eds. A. R. Piquero and S. G. Tibbetts, pp. 279-96. New York: Routledge. 
David Alan Gore Execution: Lethal Injection For Florida Rapist And Murderer Described As 'Devil' (2012, April 11). The Huffington Post http://www.huffingtonpost.com/2012/04/12/david-alan-gore-execution-lynn-elliottkiller_n_1418113.html

Demoulin, S., Rodriguez, R.T., Rodriguez, A.P., Vaes, J., Paladino, M.P., Gaunt, R., Cortes, B.P., \& Leyens, J.Ph. (2004). Emotional prejudice can lead to infra-humanization. In W. Stroebe and M. Hewstone, European Review of Social Psychology, Vol. 15. London: Psychology Press.

Demoulin, S., Cortes, B. P., Viki, T. G., Rodriguez, A. P., Rodriguez, R. T., Paladino, M. P., \& Leyens, J. Ph. (2009). The role of ingroup identification in infrahumanization. International Journal of Psychology, 44, 4-11. doi: $10.1080 / 00207590802057654$

Dowden, C., \& Andrews, D. A. (2004). The Importance of Staff Practice in Delivering Effective Correctional Treatment: A Meta-Analytic Review of Core Correctional Practice. International Journal of Offender Therapy \& Comparative Criminology, 48, 203-214. doi: 10.1177/0306624X03257765

Eberhardt, J. L., Davies, P. G., Purdie-Vaughns, V. J., \& Johnson, S. L. (2006). Looking Deathworthy Perceived Stereotypicality of Black Defendants Predicts CapitalSentencing Outcomes. Psychological Science, 17, 383-386. doi: 10.1111/j.14679280.2006.01716.x

Eberhardt, J. L., Goff, P. A., Purdie, V. J., \& Davies, P. G. (2004). Seeing Black: Race, Crime, and Visual Processing. Journal of Personality and Social Psychology, 87, 876893. doi: $10.1037 / 0022-3514.87 .6 .876$

Ferrell, J., Hayward, K., \& Young, J. (2008). Cultural Criminology: An Invitation. Sage. 
Gavin, H. (2005). The Social Construction of the Child Sex Offender Explored by Narrative. The Qualitative Report, 10, 395-413.

Giner-Sorolla, R., Leidner, B., \& Castano, E. (2011). Dehumanization, demonization, and morality shifting: Paths to moral certainty in extremist violence. In Extremism and the Psychology of Uncertainty (eds M. A. Hogg and D. L. Blaylock), Wiley-Blackwell, Oxford, UK. doi: 10.1002/9781444344073.ch10

Goff, P. A., Eberhardt, J. L., Williams, M., \& Jackson, M. C. (2008). Not yet human: Implicit knowledge, historical dehumanization, and contemporary consequences. Journal of Personality and Social Psychology, 94, 292-306. doi: $10.1037 / 0022-3514.94 .2 .292$

Gray, K., \&Wegner, D. (2009). Moral typecasting: Divergent perceptions of moral agents and moral patients. Journal of Personality and Social Psychology, 96, 505-520. doi:10.1037/a0013748

Hamdani, A. (2007). Mens rea and the cost of ignorance. Virgina Law Review, 93, 415- 457. Available at: http://www.virginialawreview.org/content/pdfs/93/415.pdf (accessed 10 April 2012).

Haslam, N. (2006). Dehumanization: An integrative review. Personality and Social Psychology Review, 10, 252-264. doi:10.1207/s15327957/pspr1003_4

Haslam, N., \& Bain, P. (2007). Humanizing the self: Moderators of the attribution of lesser humanness to others. Personality and Social Psychology Bulletin, 33, 57-68. doi:10.1177/0146167206293191

Haslam, N., Bain, P., Douge, L., Lee, M., \& Bastian, B. (2005). More human than you: Attributing humanness to self and others. Journal of Personality and Social Psychology, 89, 937-950. doi:10.1037/0022-3514.89.6.937 
Haslam, N., Kashima, Y., Loughnan, S., Shi, J., \& Suitner, C. (2008). Subhuman, inhuman, and superhuman: Contrasting humans with nonhumans in three cultures. Social Cognition, 26, 248-258. doi:10.1521/soco.2008.26.2.248

Haslam, N., \& Loughnan, S. (2012). Prejudice and Dehumanization. In J. Dixon and M. Levine (eds.), Beyond Prejudice: Extending the Social Psychology of Conflict, Inequality, and Social Change, pp. 89-105. Cambridge: Cambridge University Press.

Howells, K., \& Day, A. (1999). The Rehabilitation of Offenders: International Perspectives Applied to Australian Correctional Systems. Australian Institute of Criminology, Trends and Issues in Crime and Criminal Justice No:112. Canberra: Australia. Jahoda, G. (1999). Images of Savages: Ancient Roots of Modern Prejudice in Western Culture. London: Routledge.

Johnson, J. D., Simmons, C. H., Jordav, A., Maclean, L., Taddei, J., Thomas, D., Dovidio, J. F., \& Reed, W. (2002). Rodney King and O. J. Revisited: The Impact of Race and Defendant Empathy Induction on Judicial Decisions. Journal of Applied Social Psychology, 32, 1208-1223. doi: 10.1111/j.1559-1816.2002.tb01432.x

Kaukinen, C., \& Colavecchia, S. (1999). Public perceptions of the courts: an examination of attitudes toward the treatment of victims and accused. Canadian Journal of Criminology, 41, 365-385.

Kelman, H. G. (1973). Violence without Moral Restraint: Reflections on the Dehumanization of Victims and Victimizers. Journal of Social Issues, 29, 25-61. doi: 10.1111/j.1540-4560.1973.tb00102.x

Kury, H., \& Ferdinand, T. (1999). Public opinion and punitivity. International Journal of Law and Psychiatry, 22, 373-392. 
Leidner, B., Castano, E., Zaiser, E., \& Giner-Sorolla, R. (2010). Ingroup Glorification, Moral Disengagement, and Justice in the Context of Collective Violence. Personality and Social Psychology Bulletin, 36, 1115-1129. doi: 10.1177/0146167210376391

Levenson, J. S., Brannon, Y., Fortney, T., \& Baker, J. (2007). Public perceptions about sex offenders and community protection policies. Analyses of Social Issues and Public Policy, 7, 1-25.

Leyens, J. Ph., Rodriguez, A. P., Rodriguez, R. T., Gaunt, R., Paladino, M. P., Vaes, J., \& Demoulin, S. (2001). Psychological essentialism and the differential attribution of uniquely human emotions to ingroups and outgroups. European Journal of Social Psychology, 31, 395-411. doi: 10.1002/ejsp.50

Leyens, J. Ph., Paladino, P. M., Rodriguez, R. T., Vaes, J., Demoulin, S., Rodriguez, A. P., \& Gaunt, R. (2000). The emotional side of prejudice: The role of secondary emotions. Personality and Social Psychology Review, 4, 186-197. doi:10.1207/S15327957PSPR0402_06

Lombroso, C. (1876). L'Uomo Delinquente. Milan: Hoepli.

Lord, C. G., Lepper, M. R., \& Preston, E. (1984). Considering the opposite: A corrective strategy for social judgment. Journal of Personality and Social Psychology, 47, 12311243. doi: $10.1037 / 0022-3514.47 .6 .1231$

Loughnan, S., \& Haslam, N. (2007). Animals and androids: Implicit associations between social categories and nonhumans. Psychological Science, 18, 116-121. doi:10.1111/j.1467-9280.2007.01858.x

Loury, G. C. (2008). Race, Incarceration, and American Values. Boston: MIT.

Mann, C. R. (1989). Minority and Female: A Criminal Justice Double Bind. Social Justice, $16,95-114$. 
Myers, B., Godwin, D., Latter, R., \& Winstanley, S. (2004). Victim impact statements and mock juror sentencing: The impact of dehumanizing language on a death qualified sample. American Journal of Forensic Psychology, 22, 39-55.

Opotow, S. (1990). Moral Exclusion and Injustice: An Introduction. Journal of Social Issues, 46, 1-20. doi: 10.1111/j.1540-4560.1990.tb00268.x

Opotow, S., Gerson, J., \& Woodside, S. (2005). From moral exclusion to moral inclusion: A Theory for teaching peace. Theory into Practice, 44, 303-318. doi: 10.1207/s15430421tip4404_4

Osofsky, M. J., Bandura, A., \& Zimbardo, P. G. (2005). The Role of Moral Disengagement in the Execution Process. Law and Human Behavior, 29, 371-393. doi: 10.1007/s10979005-4930-1

Paladino, M. P., Leyens, J. Ph., Rodriguez, R. T., \& Rodriguez, A. P. (2002). Differential association of uniquely and non-uniquely human emotions with the ingroup and the outgroup. Group Process and Intergroup Relations, 5, 105-117. doi: $10.1177 / 1368430202005002539$

Prentice, D.A., \& Miller, D.T. (Eds.). (1999). Cultural divides: Understanding and overcoming group conflict. New York: Russell Sage Foundation.

Roberts, D. E. (2004). The Social and Moral Cost of Mass Incarceration in African American Communities. Stanford Law Review, 56, 1271-1305.

Sample, L. L., \& Bray, T. M. (2006). Are sex offenders different? An examination of rearrest patterns. Criminal Justice Policy Review, 17, 83-102. doi: $10.1177 / 0887403405282916$

Singer, P. (1981). The expanding circle: Ethics and socio-biology. Oxford, UK: Oxford University Press. 
Skitka, L. J. (2002). Do the means always justify the ends, or do the ends sometimes justify the means? A value model of justice reasoning. Personality and Social Psychology Bulletin, 28, 588-597. doi: 10.1177/0146167202288003

Skitka, L. J., \& Mullen, E. (2002). Understanding Judgments of Fairness in a Real-World Political Context: A Test of the Value Protection Model of Justice Reasoning Personality and Social Psychology Bulletin, 28, 1419-1429. doi:

$10.1177 / 014616702236873$

Soothill, K., \& Walby, S. (1991). Sex Crime in the News. London: Routledge.

Staub, E. (1989). The roots of evil: The origins of genocide and other group violence. New York: Cambridge University Press.

Sundt, J. L., Cullen, F. T., Applegate, B. K., \& Turner, M. G. (1998). Have Attitudes Toward Offender Treatment Changed? Criminal Justice and Behavior, 25, 426-442. doi: $10.1177 / 0093854898025004002$

Tam, T., Hewstone, M., Cairns, E., Tausch, N., Maio, G. R. \& Kenworthy, J. (2007). The impact of intergroup emotions on forgiveness in Northern Ireland. Group Processes and Intergroup Relations, 10, 119-136. doi: 10.1177/1368430207071345

Tropp, L. R., \& Pettigrew, T. F. (2009). Intergroup contact theory: Summarizing results from a meta-analytic review. In G. L. Carter (Ed.), Empirical approaches to sociology, $5^{\text {th }}$ edition. Boston: Allyn \& Bacon.

Unnever, J. D., \& Cullen, F. T. (2009). Empathetic identification and punitiveness: A middlerange theory of individual differences. Theoretical Criminology, 13, 283-312. doi: $10.1177 / 1362480609336495$

Unnever, J. D., Cullen, F. T., \& Fisher, B. S. (2005). Empathy and Public Support for Capital Punishment. Journal of Crime and Justice, 28, 1-34. doi: 10.1080/0735648X.2005.9721205 
Vaes, J., Paladino, M. P., Castelli, L., Leyens, J. Ph., \& Giovanazzi, A. (2003). On the behavioral consequences of infrahumanization: The implicit role of uniquely human emotions in intergroup relations. Journal of Personality and Social Psychology, 85, 1016-1034. doi: 10.1037/0022-3514.85.6.1016

Viki, G. T. (2011). Dehumanization and self-reported proclivity to torture: The mediating role of perceived threat. Unpublished Manuscript. University of Kent.

Viki, G.T. \& Bohner, G. (2008). Methodological limitations in measuring public attitudes to crime and punishment. In J. Wood \& T. Gannon (Eds). Public Opinion and Criminal Justice. Devon: Willan.

Viki, G.T., Culmer, M.J., Eller, A., \& Abrams, D. (2006) 'Race and willingness to co-operate with the police: the roles of quality of contact, attitudes towards the behaviour and subjective norms'. British Journal of Social Psychology, 12, 285-302. doi: 10.1348/014466605X49618

Viki, G. T., Fullerton, I., Raggett, H., Tait, F., \& Wiltshire, S. (in press). The Role of Dehumanization in Attitudes toward the Social Exclusion and Rehabilitation of Sex Offenders. Journal of Applied Social Psychology.

Viki, G. T., Zimmerman, Ballantyne, Winchester \& Measor, (2011). The Role of Perceived Humanity in Responses to Outgroups: Victim Blame and Social Exclusion. Unpublished Manuscript. University of Kent.

Waldram, J. B. (2009). "It's Just You and Satan, Hanging Out at a Pre-School:” Notions of Evil and the Rehabilitation of Sexual Offenders. Anthropology and Humanism, 34, 219-234. doi: 10.1111/j.1548-1409.2009.01039.x 
Walmsley, R. (2011). World Prison Population List (Ninth Edition). Available at: http://www.idcr.org.uk/wp-content/uploads/2010/09/WPPL-9-22.pdf (accessed 12 April 2012).

Ward, T., \& Brown, M. (2004). The good lives model and conceptual issues in offender rehabilitation. Psychology, Crime, and Law, 10, 243-257. doi: $10.1080 / 10683160410001662744$

Western, B. (2006). Punishment and Inequality in America. New York: Russell Sage Foundation.

Wood, J., \& Viki, G.T. (2004) 'Public attitudes towards crime and punishment. In J. Adler (ed.), Forensic Psychology: Debates, Concepts and Practice. Cullompton: Willan, pp. $16-36$.

Yeomans, G. C. (2010). Justice for All? The Disparate Impact of Mass Incarceration on Black Communities. Unpublished Bachelor thesis, Wesleyan University.

Zebel, S., Zimmermann, A., Viki, G. T., \& Doosje, B. (2008). Dehumanization and guilt as distinct but related predictors of support for reparation policies. Political Psychology, 29, 193-219. doi: 10.1111/j.1467-9221.2008.00623.x 